\title{
Optimization of Extraction Parameters for Keratinase Recovery from Fermented Feather under Solid State Fermentation by Streptomyces sp. NRC 13S
}

\author{
Hoda Mohamed Abdel Halim Shata · Mohamed Abdel Fattah Farid
}

Received: 15 April 2012 / Accepted: 4 June 2012 / Published Online: 30 September 2012

(C) The Korean Society for Applied Biological Chemistry 2012

\begin{abstract}
The effects of solvent type and concentration, solid/ liquid ratio, extraction time and repeated extraction on recovery of keratinase from solid-state fermentation (SSF) of chicken feather by a local Streptomyces sp. NRC $13 \mathrm{~S}$ were investigated in order to establish the experimental conditions for keratinase yield. Among solvents tested, $0.5 \%$ (v/v) glycerol was the best. BoxBehnken design was used to investigate the effect of relevant variables on keratinase recovery. The factors investigated were solid/liquid ratio (1:1.66-1:6.66 g/mL), glycerol concentration $(0.5-5 \% \mathrm{v} / \mathrm{v})$ and repeated extraction $(1-5$ cycle). The results showed that the maximum recovery of keratinase $(6933.3 \mathrm{U} / \mathrm{gfs})$ was obtained using $0.5(\mathrm{v} / \mathrm{v})$ glycerol as extracting solvent, in a solid /liquid ratio of 1:5 and three extraction cycles.
\end{abstract}

Keywords Box-Behnken design · extraction · keratinase · optimization $\cdot$ solid-state fermentation

\section{Introduction}

Keratinases (EC 3.4.21/24/99.11) have become biotechnologically important since they target the hydrolysis of highly rigid, strongly cross-linked structural polypeptide "keratin" recalcitrant to the commonly known proteolytic enzymes trypsin, pepsin and papain. These enzymes are largely produced by a variety of different microorganisms in the presence of keratinous substrates in the form of hair, feather, wool, nail, horn etc. during their degradation

Md A. F. Farid $(\bowtie)$

Natural and Microbial Products Department, National Research Center, Dokki, Cairo, Egypt

E-mail: nrcfarid@yahoo.com

H. Md A. H. Shata

Microbial Chemistry Department, National Research Center, Dokki, Cairo, Egypt
(Gupta and Ramnani, 2006). Besides their use in traditional industrial sectors like detergent, medicine, cosmetics, leather and feed (Farag and Hassan, 2004; Cai et al., 2008), keratinases also find applications in newer fields like prion degradation for treatment of the dreaded mad cow disease, biodegradable plastic manufacture and feather meal production and thus can be aptly called "modern proteases" (Langeveld et al., 2003).

Solid state fermentation (SSF) can use wastes or agro-industrial substrates for enzyme production. It is a low energy-consuming and environmentally friendly process that greatly decreases pollution problems. Because feathers and their meal are available in large amounts, they could be an interesting low-cost substrate in the fermentation industry for the production of commercial enzymes as well as for biotechnological applications (Pandy et al., 2000; Holker et al., 2004). However, one of the important aspects of SSF is the adequate recovery of enzymes from the fermented solids (Castilho et al., 1999). According to Ikasari and Mitchell (1996) extraction efficiency is a critical factor determining the economic feasibility of SSF for enzyme production. In order to make SSF applicable for the production of high-purity enzymes, some studies are found about extraction of enzymes in SSF. Therefore, when studying the solid-liquid extraction of enzymes, it is of crucial importance to test the influence of five different parameters (type of solvent, solid/ liquid ratio, temperature, agitation, and contact time) and the interrelation among them. Few studies on enzyme extraction in SSF have been reported in literature. Some reports investigated the extraction of pectinases obtained by SSF, verifying the influence of temperature, stirring rate, and time of extraction in batch and fixed bed multiple stages (Castilho et al., 1999). The extraction of xylanases obtained by SSF was also studied using experimental design technique, where the kind of solvent, the extraction temperature, the solid/liquid ratio, the stirring rate, and the extraction time were investigated (Heck et al., 2005; Diaz et al., 2007).

The purpose of this study was to investigate the extraction conditions of keratinase obtained from SSF using chicken feather 
as a substrate by Streptomyces sp. NRC 13S. The effects of the solvent type and its concentration, solid/liquid ratio, extraction time and repeated extraction on recovery of keratinase were studied. Extraction process was optimized using Box-Behenken design.

\section{Materials and Methods}

Microorganism. Streptomyces sp. NRC 13S was originally isolated from Egyptian soil and preliminarily identified as a producer of keratinase in our laboratory, Natural and Microbial Products Department, National Research center, Dokki, Cairo, Egypt. Streptomyces sp. NRC 13S was maintained on ISP2 agar slants containing $(\mathrm{g} / \mathrm{L})$ : yeast extract 4 , glucose 4 , malt extract 10 , and agar 25 (Shirling and Gottlieb, 1966).

Inoculum preparation. The spores from a fully sporulated Streptomyces sp. NRC13S slant grown on ISP2 agar slants at $28^{\circ} \mathrm{C}$ for 10 days were dispersed in three milliliters of sterile distilled water by dislodging them with a sterile loop under aseptic conditions. The spore suspension was used as inoculums for each Petri dish $(9 \mathrm{~cm})$.

Solid-state fermentation. Feathers obtained at a local poultry processing were washed with warm tap water, distilled water and then dried at $45^{\circ} \mathrm{C}$ for $48 \mathrm{~h}$ in a drying oven. After drying, feathers were cut into small fragments and milled using electric mixer. SSF was carried out by taking one gram of feather substrate in each Petri dish, and the moisture content of the meal was adjusted, unless other wise, to $66 \%$ with distilled water. After sterilization $\left(121^{\circ} \mathrm{C}, 30 \mathrm{~min}\right)$ and cooling, each Petri dish was inoculated with $1 \mathrm{ml}$ of spore suspension and incubated in an incubator with control of temperature at $30^{\circ} \mathrm{C}$ for the desired period.

Enzyme extraction. Three grams of the fermented mass in a 250 $\mathrm{mL}$ conical flask was extracted with the selected solvents by soaking the fermented feather and the mixture was mixed thoroughly on a rotary shaker $(150 \mathrm{rpm})$ at room temperature $\left(28 \pm 2^{\circ} \mathrm{C}\right)$ for 30 to $150 \mathrm{~min}$. The crude extract was then filtered through a cotton cloth and the filtrate was centrifuged at $4500 \mathrm{rpm}$ for $10 \mathrm{~min}$. The clear filtrate obtained was used for the keratinase assay. The parameters selected for this study were: solvent type and its concentration, solid/liquid ratio, extraction time and number of washes. In the experiment on the parameter pertaining to the number of washings, fresh lots of the solvent were added to the fermented feather recovered at the end of the previous extraction. Leachates from these extractions were collected separately and tested for the recovery of keratinase.

Selection of extraction solvent for keratinase. Different solvents were tested for extraction of keratinase: distilled water, tap water, glycerol (1\% v/v), $0.1 \mathrm{M}$ glycine buffer ( $\mathrm{pH} 8,9,10,11), 0.1 \mathrm{M}$ sodium phosphate buffer $(\mathrm{pH} 6.0,7.0,8.0), \mathrm{NaCl}$ solution $(10 \%$ $\mathrm{w} / \mathrm{v}$ ), and non-ionic detergents such as Tween 20, Tween 40, Tween 60, Tween 80 and Triton X-100. The kinds of solvents, the range of $\mathrm{pH}$ and concentration were chosen based on some previous studies of extraction of proteases (Tunga et al., 1999;
Table 1 Coded values of variables used in Box-Behnken design

\begin{tabular}{lccc}
\hline \multirow{2}{*}{ Independent variables } & \multicolumn{3}{c}{ Level } \\
\cline { 2 - 4 } & -1 & 0 & 1 \\
\hline $\mathrm{X}_{1}$ : Solid/liquid ratio $(\mathrm{g} / \mathrm{mL})$ & $1: 2.5$ & $1: 5$ & $1: 7.5$ \\
$\mathrm{X}_{2}$ : Glycerol concentration $(\%, \mathrm{v} / \mathrm{v})$ & 0.25 & 0.5 & 0.75 \\
$\mathrm{X}_{3}$ : Repeated extractions (number) & 1 & 2 & 3 \\
\hline
\end{tabular}

Aikat and Bhattacharyya, 2000; De Azeredo et al., 2006; Sumantha et al., 2006).

Keratinase assay. Keratinase activity was determined using method of Friedrich et al. (1999) with some modifications. 0.25 $\mathrm{mL}$ of crude enzyme with $0.75 \mathrm{~mL}$ keratin powder $(1 \% \mathrm{w} / \mathrm{v})$ in $0.1 \mathrm{M}$ glycine buffer $\mathrm{pH} 7.8$ for half an hour at $40^{\circ} \mathrm{C}$ in a shaking water bath. The reaction was stopped by adding $0.5 \mathrm{~mL}$ of $15 \%$ trichloroacetic acid (TCA). After half an hour, centrifugation was done at $4000 \mathrm{rpm}$ for $10 \mathrm{~min}$ and the released amino acids were estimated according to Lowry et al. (1951). One unit of the enzyme activity (U) was defined as the amount of the enzyme that liberates $1 \mu \mathrm{g}$ of amino acids equivalent to tyrosine per min under the experimental conditions. Enzyme yield was expressed as units per gram fermented substrate (U/gfs).

Optimization of extraction parameters for recovery of Keratinase. Based on the results of the one-variable-at-a-time experiment, response surface methodology (RSM) was used to optimize keratinase extraction using Box-Behnken design (Box and Behnken, 1960). The behavior of the system was explained by the following quadratic equation,

$$
Y=\beta 0+\beta i X i+\beta i j X i X j+\beta i i X^{2} i
$$

Where $Y$ is the predicted response variable; $\beta 0, \beta i$, $\beta i i, \beta i j$ are constant regression coefficients of the model, and $X i, X j(i=1,3$; $j=1,3, i j$ ) represent the independent variables in the form of coded values. Statistical software package Design-Expert (Version 8.0.2, State-Ease, USA) was used to design and analyze the experiment. A $2^{3}$ factorial design, with three replicates at the centre point with total number of 15 trials was employed. The accuracy and general ability of the above polynomial model could be evaluated by the coefficient of determination $\mathrm{R}^{2}$. The coded values of the variables at various levels are given in Table 1 .

\section{Results and Discussion}

Solvent Selection. The selection of a suitable solvent is critical to the recovery of the enzyme from the solid fermented biomass and one of important aspect of SSF. An ideal solvent would extract the enzyme selectively and completely at room temperature with minimal contact time and, preferably, at the $\mathrm{pH}$ of the cultivated substrate (Singh et al., 1999). As shown in Fig. 1(A), among the solvents tested glycerol $1 \%(\mathrm{v} / \mathrm{v})$ gave the highest yield of keratinase (3200 U/gfs) from the fermented solid feather. The other organic solvents (Tween 60, Triton X-100 and glycine buffer) gave good results for recovery of the enzyme from the fermented mass, which indicate that organic solvents are more effective as 

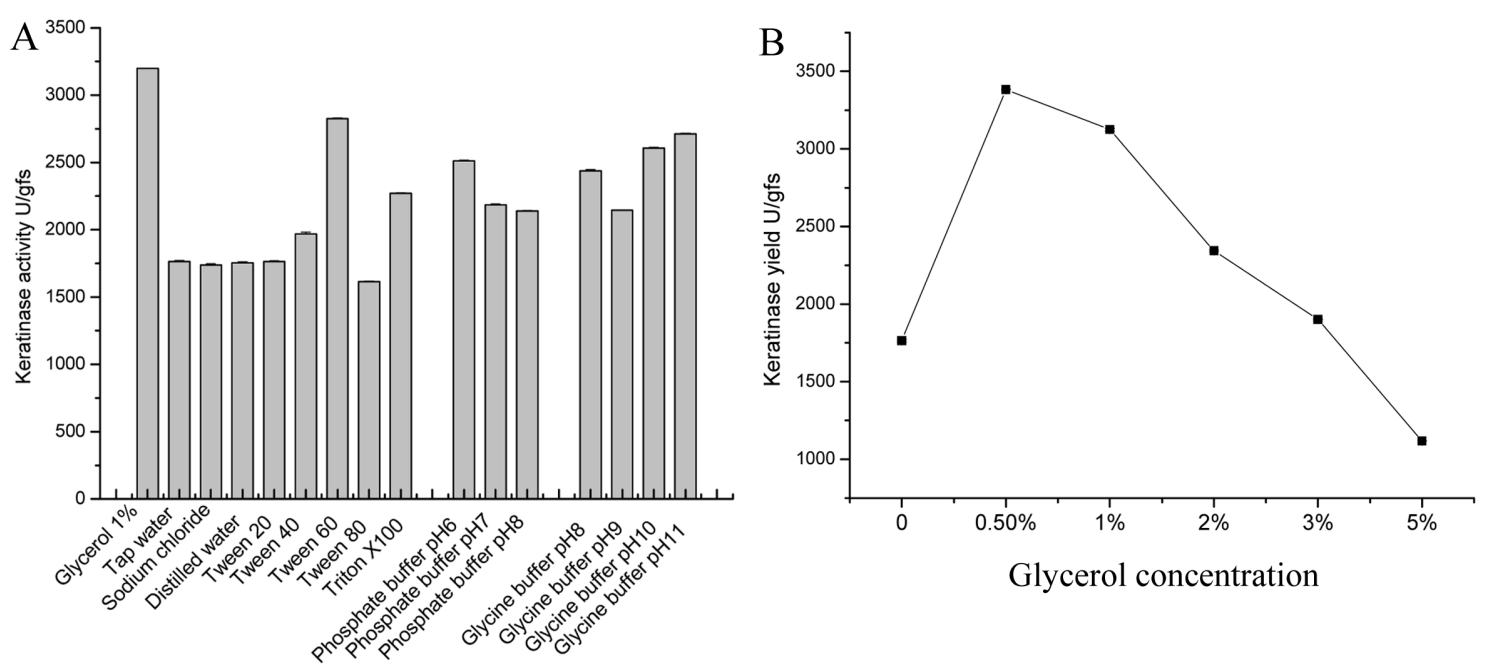

Extraction solution
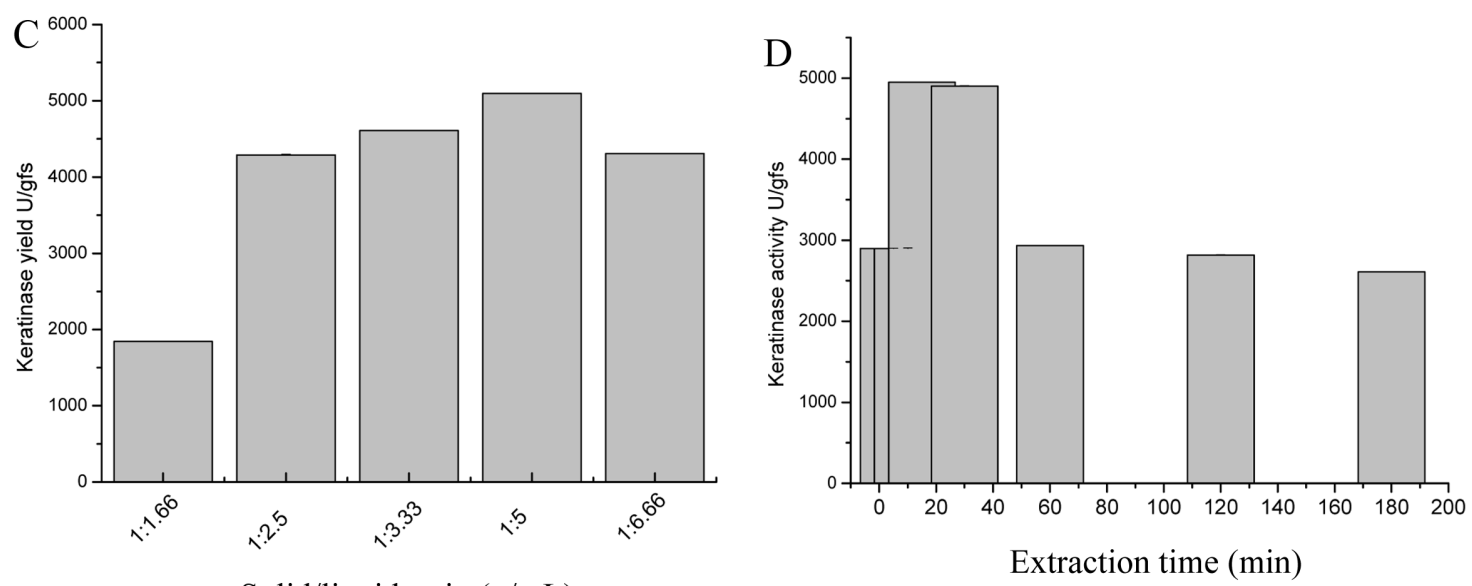

Solid/liquid ratio $(\mathrm{g} / \mathrm{mL})$

Fig. 1 Effect of different solutions (A), glycerol concentration (B), solid/liquid ratio (C) and extraction time (D) on keratinase recovery from fermented feather under SSF.

extracting media than water or $\mathrm{NaCl}$ solution. Glycerol at a concentration of $2.5 \%(\mathrm{v} / \mathrm{v})$ was found to be the best solvent for extraction of á-amylase from the fermented wheat bran by Bacillus circulan GRs313 (Palit and Banerjee, 2001). At this concentration the hydroxyl group of the glycerol forms hydrogen bond with the protein molecules, which gives better stability to the enzyme molecule. Palit and Banerjee (2001) explained this reason by Debye-Hickel theory (Maron and Prutton, 1965):

$$
\mathrm{F}=\mathrm{I} / \mathrm{D} /(\mathrm{Q} 1 \mathrm{Q} 2) / \mathrm{r}^{2}
$$

Where $\mathrm{F}=$ force of attraction or repulsion, $\mathrm{D}=$ dielectric constant, $\mathrm{Q} 1, \mathrm{Q} 2=$ charges of the attracting molecules, $\mathrm{r}=$ distance of two attracting molecules. All solvents have its own dielectric constant, organic solvents posses lower dielectric constant than inorganic solvents, so water possesses higher dielectric constant than organic solvents, therefore from the above theory it can be concluded that force of interaction between keratinase and solvent may have increased due to lowered dielectric constant of the extracting solvent, glycerol. Though other organic solvent posses lower dielectric constant than glycerol they may have some inhibitory effect on enzyme activity.

On the other hand, the results show that phosphate buffer at all pHs proved to be better than $\mathrm{NaCl}$ or water. These results are in accordance with that reported by Chen et al. (2011). They mentioned that sodium acetate buffer of $\mathrm{pH} 4.5$ gave the better recovery of inulinase from fermented solid than water and $\mathrm{NaCl}$ solution. The use of citrate-phosphate buffer ( $\mathrm{pH} \mathrm{4.0)}$ to leach other enzymes such as $\alpha$-galactosidase from the fermented mass has been reported before (Annunziato et al., 1986). Soares et al. (2003) also demonstrated that water was the best solvent for transglutaminase extraction on solid-state cultivation. In many works on solid-state production of xylanases, the solvent used has been either acetate buffer, $\mathrm{pH}$ around 5.0 or water. Water has a higher dielectric constant compared with organic solvents. When the dielectric constant is decreased, the interaction forces between xylanase and solvent may increase; therefore, loss of enzymes 
would increase (Heck et al., 2002).

Glycerol concentration. Leaching, a process for recovering the solute from the solids in the form of crude extract using the appropriate solvent is an important unit operation (Treybal, 1981). Various factors are known to influence the degree of leaching of the product from the fermented substrate produced by solid-state fermentation (Lonsane and Krishnaiah, 1992). Among using different concentrations of glycerol $(0.5$ to $5 \% \mathrm{v} / \mathrm{v})$, Fig. 1 (B) shows that $0.5 \%(\mathrm{v} / \mathrm{v})$ glycerol was the concentration which provided maximum keratinase extraction, whereas glycerol at high concentrations gave less yield in the enzyme extraction from the fermented biomass. It was reported that at high glycerol concentrations there might be some inhibitory effect due to distortion of enzyme structure (Stryer, 1975). The poor performance of glycerol at high concentration $(50 \% \mathrm{v} / \mathrm{v})$ during extraction of pectinase can be explained by its higher viscosity, which has a negative effect on mass transfer. However, it was mentioned that only with glycerol no decrease in both polygalacturonase and pectinase activities was observed beyond $35^{\circ} \mathrm{C}$. This was due to the protective effect of glycerol on enzyme activity (Castilho et al., 2000). Glycerol forms strong hydrogen bonds with water, reducing the water activity. Enzymes which would rapidly lose their activity may keep active even at higher temperatures in the presence of glycerol (Scopes, 1982).

Solid to solvent ratio. The ratio of solvent-to-solid plays an important role in the extraction of enzymes from the fermented biomass. In the solid-state fermentation system, free flowing solvent is very much limited. Thus, adequate amount of the solvent is required to leach out the enzyme present (Palit and Banerjee, 2001). The volume of the solvent $(0.5 \%(\mathrm{v} / \mathrm{v})$ glycerol $)$ was varied from 1.66 to $6.66 \mathrm{~mL} / \mathrm{gfs}$ and the extraction process was carried out on a rotary shaker $(150 \mathrm{rpm})$ at room temperature $\left(28 \pm 2^{\circ} \mathrm{C}\right)$ for $60 \mathrm{~min}$. It was found that solid/ liquid ratio of 1:5 ( $\mathrm{g} / \mathrm{mL}$ ) was optimum Fig. 1(C). The total activity decreased when lower volume of the solvent was used for extraction. Recovery of the low yield of enzyme from the fermented feather with lower volume of solvent might be due to the insufficient solvent volume to penetrate the solid fermented mass. Higher solvent to solid ratios also causes the solute to be more dilute in the final extract. The increase in leaching efficiency gained at higher ratios must, therefore, be balanced against the extra effort for concentration of the dilute extract (Lonsane and Krishnaiah, 1992). Also, it was mentioned that increasing the ratio of leaching solution $(5 \%(\mathrm{w} / \mathrm{v})$ $\mathrm{NaCl})$ to moldy bran increases protease recovery, however, with high ratios more solvent is consumed, larger vessels are required for the leaching process, and the extract is more dilute. Lower ratios give lower recoveries because a significant fraction of the leaching solution is retained in the bran (Ikasari and Mitchell, 1996).

Effect of extraction time. The volume of $0.5 \%$ glycerol in relation to the solid matrix was retained at the optimal level (1:5 $\mathrm{g} / \mathrm{mL}$ ), and the incubation time for extraction was further optimized for maximum enzyme recovery from the fermented feather. The time period was varied from 5 to $180 \mathrm{~min}$ (Fig. 1D).

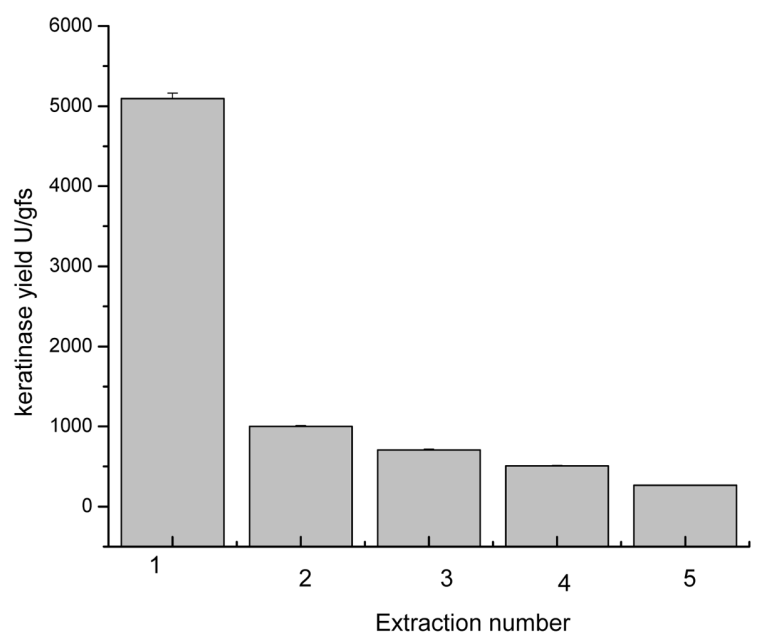

Fig. 2 Effect of extraction number on keratinase recovery from fermented feather under SSF. Note: X1: solid/liquid ratio $(\mathrm{g} / \mathrm{mL}) ; \mathrm{X} 2$ : glycerol concentration $(\%, v / v)$; X3: repeated extractions (number).

Fifteen minutes extraction time was optimum, and thereafter no beneficial effect on the keratinase extraction was observed, indicating the minimum time for total penetration of the solvent through the fermented biomass. Further increase in the contact time slightly decreased the leaching of the enzyme. Lonsane and Krishnaiah, (1992) mentioned that short leaching times maximize the volumetric productivity of the leaching equipment. Solidsolvent contact time is another factor governing the efficiency of leaching. In the present study, 15 min contact time between the solvent and the solid achieved maximum recovery of the keratinase. Drop in the recovery of the enzyme at the higher contact time may be due to the inactivation of the enzyme. Soaking of the fermented bran substrate in $0.1 \mathrm{M}$ citrate buffer $\mathrm{pH} 4$ at $22^{\circ} \mathrm{C}$ for $1 \mathrm{~h}$ was used for the recovery of acid protease (Ikasari and Mitchell, 1996). A contact time of $180 \mathrm{~min}$ with occasional agitation was employed for the leaching of milk-clotting enzyme from the fermented bran, whereas 150 min soaking for amylase extraction was reported (Palit and Banerjee, 2001; Shata, 2005). On the other hand, Chandra et al. (2008) found that 90 min contact time at $30^{\circ} \mathrm{C}$ was optimum for extraction of filter-paperase from fermented bran by Aspergillus niger.

Repeated extractions. The efficiency of extraction of the enzyme from the fermented feather with $0.5 \%$ glycerol at the optimal solid: liquid ratio $(1: 5 \mathrm{~g} / \mathrm{mL})$ was carried out in five cycles of 15 min each. Fresh solvent was added in each cycle to the same fermented feather. As shown in Fig. 2, the first extract had maximum activity of more than $67.7 \%$, the second extract (13.2\%) and the third extract (9.34\%) represent about $89.77 \%$ of the total activity. Subsequent extractions did not have any significant enzyme activity.

Optimization of extraction parameters for keratinase recovery. After establishing the different factors (solvent type, solvent concentration, solid/solvent ratio, effect of extraction time and repeated extractions) to leach the keratinase from solid matrix and 
Table 2 Box-Behnken design matrix with experimental and predicted values of keratinase recovery

\begin{tabular}{|c|c|c|c|c|c|}
\hline \multirow{2}{*}{ Run } & \multirow{2}{*}{$\begin{array}{c}\text { X1 } \\
\text { Solid: Liquid } \\
(\mathrm{g} / \mathrm{mL})\end{array}$} & \multirow{2}{*}{$\begin{array}{c}\mathrm{X} 2 \\
\text { Glycerol concentration } \\
(\%)\end{array}$} & \multirow{2}{*}{$\begin{array}{c}\text { X3 } \\
\text { Repeated extractions } \\
\text { (number) }\end{array}$} & \multicolumn{2}{|c|}{ Keratinase yield (U/gfs) } \\
\hline & & & & Experimented & Predicted \\
\hline 1 & -1 & 0 & -1 & 4467 & 4692.96 \\
\hline 2 & -1 & 0 & 1 & 5324.1 & 5268.41 \\
\hline 3 & 1 & 0 & -1 & 3492.4 & 3548.09 \\
\hline 4 & 1 & 0 & 1 & 6933.3 & 6707.34 \\
\hline 5 & 0 & 0 & 0 & 6893.2 & 6887.93 \\
\hline 6 & 0 & 1 & -1 & 4122.8 & 4082.04 \\
\hline 7 & 0 & -1 & 1 & 5131.6 & 5172.36 \\
\hline 8 & 0 & -1 & -1 & 3470 & 3229.11 \\
\hline 9 & 1 & 1 & 0 & 4953.9 & 4938.98 \\
\hline 10 & -1 & -1 & 0 & 4000 & 4014.93 \\
\hline 11 & 0 & 1 & 1 & 5632.6 & 5873.49 \\
\hline 12 & 0 & 0 & 0 & 6851.4 & 6887.93 \\
\hline 13 & 1 & -1 & 0 & 4907.4 & 5092.6 \\
\hline 14 & -1 & 1 & 0 & 5907.8 & 5722.6 \\
\hline 15 & 0 & 0 & 0 & 6919.2 & 6887.93 \\
\hline
\end{tabular}

Table 3 Regression analysis for keratinase recovery for quadratic response surface model fitting (ANOVA)

\begin{tabular}{|c|c|c|c|c|c|}
\hline Source & $\begin{array}{l}\text { Sum of } \\
\text { Squares }\end{array}$ & $\begin{array}{c}\text { Degrees } \\
\text { of freedom }\end{array}$ & $\begin{array}{l}\text { Mean } \\
\text { Squares }\end{array}$ & $\begin{array}{c}\mathrm{F} \\
\text { Value }\end{array}$ & $\begin{array}{l}p \text {-value } \\
\text { Prop }>\text { F }\end{array}$ \\
\hline Model & $2.11 \mathrm{E}+07$ & 9 & $2.34 \mathrm{E}+06$ & 39.17 & $0.0004 *$ \\
\hline $\mathrm{X} 1$ & 43232.7 & 1 & 43232.7 & 0.72 & 0.4341 \\
\hline $\mathrm{X} 2$ & $1.21 \mathrm{E}+06$ & 1 & $1.21 \mathrm{E}+06$ & 20.19 & $0.0064^{*}$ \\
\hline $\mathrm{X} 3$ & $6.97 \mathrm{E}+06$ & 1 & $6.97 \mathrm{E}+06$ & 116.59 & $0.0001 *$ \\
\hline $\mathrm{X} 1 \mathrm{X} 2$ & $8.66 \mathrm{E}+05$ & 1 & $8.66 \mathrm{E}+05$ & 14.48 & 0.0126 \\
\hline $\mathrm{X} 1 \mathrm{X} 3$ & $1.67 \mathrm{E}+06$ & 1 & $1.67 \mathrm{E}+06$ & 27.9 & $0.0032 *$ \\
\hline $\mathrm{X} 2 \mathrm{X} 3$ & 5760.81 & 1 & 5760.81 & 0.096 & 0.7688 \\
\hline$X 1^{2}$ & $2.02 \mathrm{E}+06$ & 1 & $2.02 \mathrm{E}+06$ & 33.83 & $0.0021 *$ \\
\hline$X 2^{2}$ & $5.36 \mathrm{E}+06$ & 1 & $5.36 \mathrm{E}+06$ & 89.68 & $0.0002 *$ \\
\hline$X 3^{2}$ & $4.41 \mathrm{E}+06$ & 1 & $4.41 \mathrm{E}+06$ & 73.79 & $0.0004 *$ \\
\hline Residual & $2.99 \mathrm{E}+05$ & 5 & 59816.13 & & \\
\hline Lack of Fit & $2.97 \mathrm{E}+05$ & 3 & 98913.54 & 84.54 & 0.0117 \\
\hline Pure Error & 2340.03 & 2 & 1170.01 & & \\
\hline Cor Total & $2.14 \mathrm{E}+07$ & 14 & & & \\
\hline R-Squared & 0.986 & & & & \\
\hline Adj. R-squared & 0.9608 & & & & \\
\hline
\end{tabular}

Note: X1: solid/liquid ratio $(\mathrm{g} / \mathrm{mL}) ; \mathrm{X} 2$ : glycerol concentration $(\%, \mathrm{v} / \mathrm{v}) ; \mathrm{X} 3$ : repeated extractions (number), Cor: correlation, * Values of "probability $>$ F" less than 0.05 indicate model terms are significant.

in order to approach the optimum condition for keratinase extraction, response surface methodology (RSM) was used to optimize the extraction parameters for enhancing keratinase recovery. A BoxBehnken factorial design with three factors and three levels including three replicates at the center point was used for fitting a second-order response surface (Box and Behnken, 1960). Based on the above results; glycerol concentration, solid/liquid ratio and repeated extraction were selected as effective variables for keratinase extraction. A total of 15 experiments with different combinations of solid/liquid ratio $\left(\mathrm{X}_{1}\right)$, glycerol concentration $\left(X_{2}\right)$ and repeated extractions $\left(X_{3}\right)$ were performed (Table 2$)$. The results were analyzed by standard analysis of variance (ANOVA) and the following quadratic regression equation was obtained in terms of keratinase yield.

$$
\begin{aligned}
\mathrm{Y}= & 6887.93333+73.51250 \mathrm{X}_{1}+388.51250 \mathrm{X}_{2}+933.67500 \mathrm{X}_{3} \\
& -465.32500 \mathrm{X}_{1} \mathrm{X}_{2}+645.95000 \mathrm{X}_{1} \mathrm{X}_{3}-37.95000 \mathrm{X}_{2} \mathrm{X}_{3} \\
& -740.35417 \mathrm{X}_{1}^{2}-1205.30417 \mathrm{X}_{2}^{2}-1093.37917 \mathrm{X}_{3}^{2}
\end{aligned}
$$

Keratinase yield varied from 3470 to $6933 \mathrm{U} / \mathrm{gfs}$ according to different levels of selected factors. The lowest yield was observed for run No. 3 and 8 while the highest yield of U/gfs was obtained with run No. 4 . These results suggest that the glycerol concentration and repeated extraction strongly affect keratinase yield. However, when the solid/liquid ratio is considered, it is interesting to note 
A

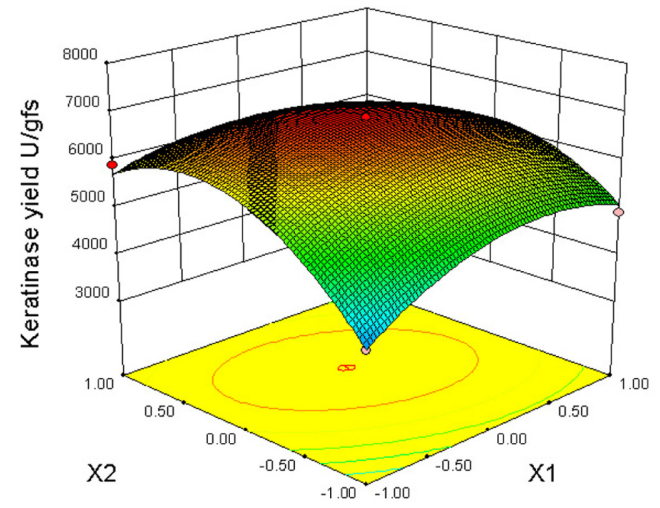

C

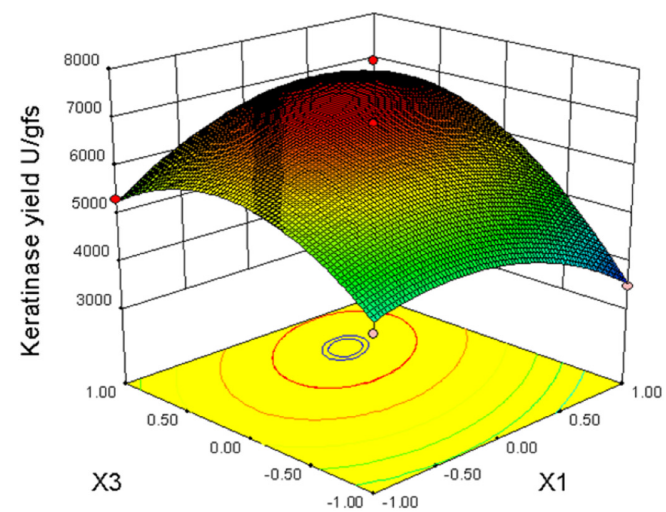

$\mathrm{E}$

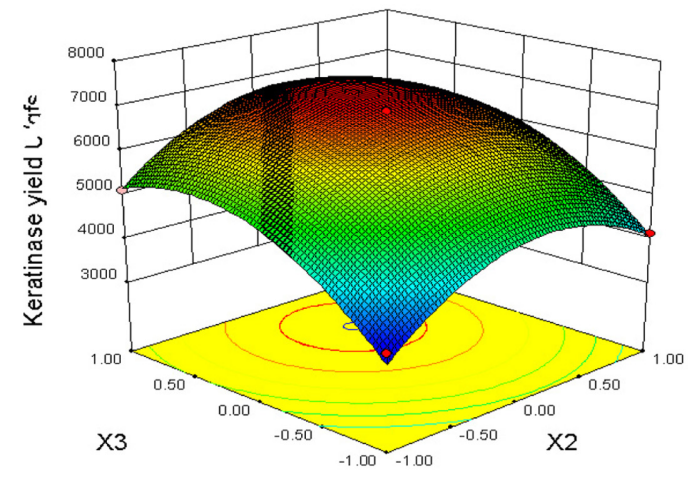

B

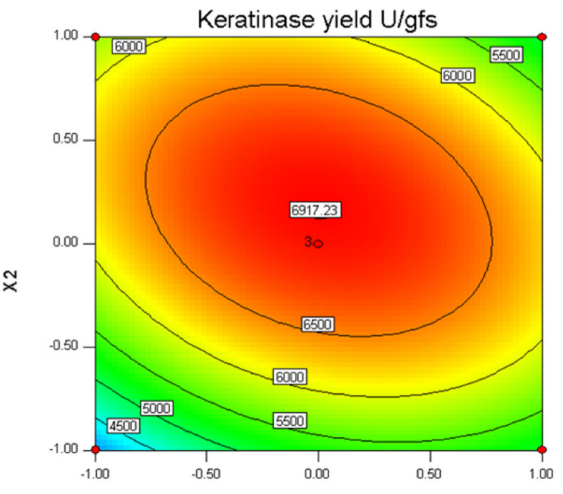

$\mathrm{D}$

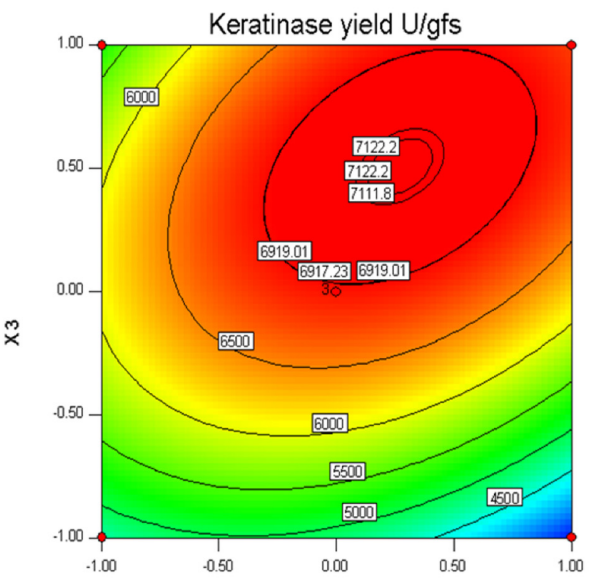

$\mathrm{X} 1$

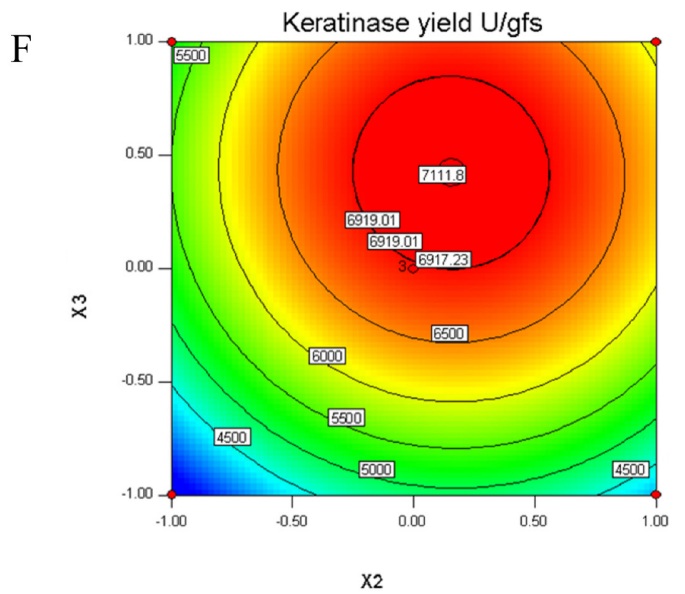

Fig. 3 Surface and contour plots of combined effect of solid /liquid ratio and glycerol concentration (A, B), solid/liquid ratio and repeated extraction $(\mathrm{C}, \mathrm{D})$, glycerol concentration, and repeated extraction $(\mathrm{E}, \mathrm{f})$ on the recovery of keratinase from fermented feather under SSF.

that keratinase yield increase with the increase solid/liquid ratio up to $1: 5(\mathrm{w} / \mathrm{v})$ with no significant variation for ratios above this ratio.

The significance of each regression coefficient was determined by $p$-values, which are listed in Table 3 . Values of "Prob $>F$ " less than 0.05 indicate model terms are significant. In this case, glycerol concentration (X2), repeated extraction (X3), their inter action with with solid/liqued ratio (X1X2 and X1X3) are significant model termes. The quadratic effects of $\mathrm{X}^{2}, \mathrm{X} 2^{2}$ and $\mathrm{X} 3^{2}$ are also significant model terms. The quadratic terms for the three variables indicated that they can act as limiting factors even small increase in their values will significantly increase or decrease keratinase yield, respectively (Adinarayana and Suren, 2005). Values greater than 0.1 indicate the model terms are not 
significant.

The goodness of fit of the model was cheked by determination coefficient $\left(\mathrm{R}^{2}\right)$. In this case, the value of the determination coefficient $\left(\mathrm{R}^{2}=98.6\right)$ indicated that only $1.4 \%$ of the total variation were not explained by the model. The value of the adjusted determination coefficient (Adj $\mathrm{R}^{2}=0.9608$ ) was also very high to advocate for a high significane of the model. The "Pred RSquared" of 0.7778 is in reasonable agreement with the "Adj RSquared" of 0.9608 . At the same time, a relatively lower value of the coefficient of variation $(\mathrm{CV}=4.64)$ indicated a good precision and reliability of the experiments carried out.

Figure 3 shows the response surface plots and their contour plots of keratinase yield during the extraction process. An elliptical nature of the contour plots indicates that the interactions between the independent variables are significant. Since interactions between the three independents are observed from Table 3 for $X_{1} X_{2}$ and $\mathrm{X}_{1} \mathrm{X}_{3}$ an elliptical contour plots are found in Fig. 3B and 3C.

Evidently, keratinase yield varied significantly upon changing the sold/liquued ratio, glycerol concentation or repeated extractions. Under certain condition (glycerol con. $=0.525-0.55 \% \mathrm{v} / \mathrm{v}$ ) coded as $0.1-0.2$, solid/liquid raio $(1: 5.25-1: 5.66 \mathrm{~g} / \mathrm{mL})$ coded as $0.15-$ 0.4 , and repeated extraction coded as $0.37-0.58$ ), a maximal contour ( $\mathrm{Y}$ activity $=7122$ ) could be determined (Fig. 3D) meaning that further increase of $\mathrm{X} 1, \mathrm{X} 2$ and $\mathrm{X} 3$ would not increase the keratinase yield any longer.

Comparison of observed and predicted. A regression model can be used to predict future observations on the response (keratinase yield) during the hydrolysis process corresponding to particular values of the repressor variables. Table 2 shows also the observed keratinase yield (the response) and their predicted value. The results prove that the predicted data of the response from the empirical model are in agreement with the observed ones in the range of the operating variables.

In conclusion, the effect of solid/liquid ratio, glycerol concentration and repeated extraction on recovery of keratinase from fermented chicken feather by Streptomyces sp. NRC 13S under solid state fermentation were investigated. The extraction parameters were optimized by Box- Behnken design resulting in keratinase activity values of $6933.3 \mathrm{U} / \mathrm{gfs}$, when using solid/liquid ratio of 1:5 (g/ $\mathrm{mL})$, glycerol concentration $0.5 \%(\mathrm{v} / \mathrm{v})$ and three repeated extraction cycles.

Acknowledgment This work was supported by Microbial Chemistry Department and Natural and Microbial Products Department, National Research Center, Dokki, Cairo, Egypt.

\section{References}

Adinarayana K and Suren S (2005) Response surface optimization of enzymatic hydrolysis of maize starch for higher glucose production. Biochem Eng $J$ 27, 179-90.

Aikat K and Bhattacharyya BC (2000) Protease extraction in solid state fermentation of wheat bran by a local strain of Rhizopus oryzae and growth studies by soft gel technique. Proc Biochem 35, 907-14.

Annunziato ME, Mahoney RR, and Mudgett RE (1986) Production of $\alpha$ - galactosidase from Aspergillus oryzae grown in solid state culture. $J$ Food Sci 51, 1370.

Box GEP and Behnken DW (1960) Some new three level designs for the study of quantitative variables. Technometrics 2, 455-75.

Cai CG, Lou BG, and Zheng XD (2008) Keratinase production and keratin degradation by mutant strain of Bacillus subtilis. J Zhejiang Univ Sci B 9, 60-7.

Castilho LR, Alves TLM, and Medronho RA (1999) Recovery of pectolytic enzymes produced by solid-state cultureof Aspergillus niger. Process Biochem 34,181-6.

Castilho LR, Medronho RA, and Alves TLM (2000) Production and extraction of pectinases obtained by solid state fermentation of agroindustrial residues with Aspergillus niger. Bioresource Technol 71, 4550 .

Chandra MS, Reddy RB, and Choi Y (2008) Optimization of Extraction of Fpase from the Fermented Bran of Aspergillus niger in Solid State Fermentation. J Appl Biol Chem 51, 155-9.

Chen H, Chen X, Chen T, Xu X, and Jin Z (2011) Extraction optimization of inulinase obtained by solid state fermentation of Aspergillus ficuum JNSP5-06. Cabohyd Polym 85, 446-51.

de Azeredo LAI, Lima MB, De-Coleho RRR, and Freire DMG (2006) Thermophilic protease production by Streptomyces sp. 594 in submerged and solid state fermentation using feather meal. J Appl Microbiol 100, 641-7.

Díaz AB, Caro I, Ory ID, and Blandino A (2007) Evaluation of the conditions for the extraction of hydrolytic enzymes obtained by solid state fermentation from grape pomace. Enzyme Microb Technol 41, 302-6.

Farag AM and Hassan MA (2004) Purification, characterization and immobilization of a keratinase from Aspergillus oryzae. Enzyme Microb Technol 34, 85.

Friedrich J, Gradisar H, Mandin D, and Chaumont JP (1999) Screening fungi for synthesis of kerationlytic enzymes. Lett Appl Microbiol 28, 127-30.

Gupta R and Ramnani P (2006) Microbial keratinases and their prospective applications: An overview. Appl Microbiol Biotechnol 70, 21-33.

Heck JX, Hertz PE, and Ayub MAZ (2002) Cellulase and xaylanase production by isolated Amazon bacillus strains using soybean industrial residue based solid-state cultivation. Brazilian J Microbiol 33, 212-8.

Heck JX, Hertz PF, and Ayub MAZ (2005) Extraction optimization of xylanases obtained by solid-state cultivation of Bacillus circulans BL53. Process Biochem 40, 2891-5.

Holker U, Hofer M, and Lenz J (2004) Biotechnological advantages of laboratory-scale solide-state fermentation with fungi. Appl Microbiol Biotechnol 64, 175-86.

Ikasari L and Mitchell DA (1996) Leaching and characterization of Rhizopus oligosporus acid protease from solid-state fermentation. Enzyme Microb Technol 19, 171-5.

Langeveld JPM, Wang JJ, van de Wiel DFM, Shih GC, Garssen GJ, Bossers A et al. (2003) Enzymatic degradation of prion protein in prain stem from infected cattle and sheep. $J$ Infect Dis 188, 1782-9.

Lonsane BK and Krishnaiah MM (1992) Product leaching and downstream processing. In Solid substrate Cultivation, Doelle HW, Mitchell DA, and Rolz CE (eds.) pp. 147-53. Elsevier Science Publishers, UK.

Lowry OH, Rosenbrourgh NJ, Farr NJ, and Randall JR (1951) Protein measurement with the Folin phenol reagent. $J$ Biol Chem 193, 265-75.

Maron SH and Prutton CF (1965) In Principles of Physical Chemistry. (4th ed.), Oxford and IBH Publishing Co. Pvt. Ltd., India.

Palit S and Banerjee R (2001) Optimization of extraction parameters for recovery of $\alpha$-amylase from the fermented bran of Bacillus circulans GRS313. Braz Arch Biol Technol 44, 107-11.

Pandy A, Soccol, CR, and Mitchell D (2000) New development in solid-state fermentation: 1- Bioprocess and products. Process Biochem 35, 1153-69.

Scopes RK (1982) Protein Purification: Principles and Practice. Springer, USA

Shata HA (2005) Extraction of milk-clotting enzyme produced by solid state fermentation of Aspergillus oryzae. Pol J Microbiol 54, 241-7.

Shirling EB and Gottlieb D (1966) Methods for characterization of Streptomyces species. Int J Syst Bacteriol 16, 313-40.

Singh SA, Ramakrishn M, and Rao AGA (1999) Optimization of down 
stream processing parameters for the recovery of pectinase from the fermented bran of Aspergillus carbonarius. Process Biochem 35, 411-7.

Soares LHB, Assmann F, and Ayub MAZ (2003) Production of tranglutaminase from Bacillus circulans on solid-state and submerged cultivations. Biotechnol Lett 25, 2029-33.

Stryer L (1975) Biochemistry. (2nd ed.), W.H. Freeman and Company, New York, USA.

Sumanth A, Larroche C, and Pandey A (2006) Microbiology and industrial biotechnology of food-grade protease: A perspective. Food Technol Biotechnol 44, 211-20.

Treybal RW (1981) In Mass Transfer Operations. p. 737, Kin Keong Printing Co. Ltd., Singapore.

Tunga R, Banerjee R, and Bhattacharya BR (1999) Some studies on optimization of extraction process for protease production in SSF. Bioprocess Eng 20, 485-9. 